Ethiopian Journal of Environmental Studies \& Management 8(Suppl. 2): 916 - 925, 2015.

ISSN:1998-0507

doi: http://dx.doi.org/10.4314/ejesm.v8i2.6S

Submitted: July 04, 2015

Accepted: November 06, 2015

\title{
TREE SPECIES DIVERSITY IN KAKULU FOREST OF ZING L.G.A., TARABA STATE, NIGERIA
}

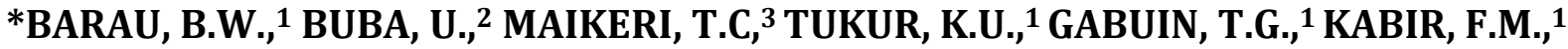 \\ THOMAS, T.L. ${ }^{1}$ AND DANBA, E.P. ${ }^{1}$ \\ ${ }^{1}$ Department of Biological Sciences, Taraba State University, P. M. B 1167, Jalingo, Taraba \\ State, Nigeria \\ ${ }^{2}$ Department of Animal Science, Taraba State University, P. M. B 1167, Jalingo, Taraba State, \\ Nigeria \\ ${ }^{3}$ Department of Basic Science, College of Agriculture, Jalingo
}

\begin{abstract}
Trees make a forest and in order to understand the forest we must know about the trees. This study was design to establish an understanding of the trees species diversity of Kakulu forest using plots within and between tilled and untilled fragments. The result revealed an interspersion of savanna trees species to be occurring in Kakulu forest. The Shannon Diversity Index was used to determine species diversity, while the Shannon Equitability was also used to elucidate the evenness of species within plots. For the tilled fragment Isobalinia tormentosa had the highest Relative Density (RD) of 24.6 while Brigdelia ferruginea and Cussonia barterii were the least with Relative Dendity of 0.2. In the untilled fragment Isobaliniadoka had the highest Relative Density of 34.6 while Terminalia ancennoides, Ekerbegia senegalensis, Danielia oliveri and Cussonia barterii were the least with Relative Density of 0.1 each. The two fragments have diversity indices of $H_{1}=2.3505$ and $H_{2}=2.3448$ and equitability values of 0.1473 and 0.1611 respectively. Furthermore, there was no significant difference $(P>0.05)$ of tree species diversity in the forest fragments, but there was a significant difference in tree species within fragments ( $p>0.05)$. The family Fabaceae had the highest percentage abundance (60.92\%) while Maliaceae has the lowest (0.07\%). Therefore, any observed difference within the study area may be an indication of deforestation requiring urgent replacement to prevent further demise.
\end{abstract}

Key Words: Forest, Trees, Diversity, Abundance, Kakulu, Zing

\section{Introduction}

Nigerian vegetation is one of the most endowed in Africa, as all the vegetation types existing in other African countries are found widely distributed in different geographical zones of the country (Adeyimi and Ogundipe, 2012). The interspersion of vegetation types found in Nigeria is an indication of favorable climatic conditions which is also favored

*Corresponding author: Barau, B.W.

Email: bilyaminubarau@yahoo.co.uk by the variations in climate and geographical features. Nigeria harbors about 7,895 species of plant thereby making it one of the richest biodiversity hotspot in the continent (Adeyimi and Ogundipe, 2012; Nodza et al., 2014).

Forest degradation and habitat destruction due to anthropogenic activities are the major causes of global biodiversity decline and reconstruction of disturbed 
ecosystem is being taken up as a priority basic for the maintenance of landscape productivity and biodiversity conservation (Solbrig, 1991; Davis and Richardson, 1995). It is pertinent to note that ecosystemic changes are largely due to man's unwanton handling of his immediate environment. A major challenging task confronting ecologist and other environmentalists is, understanding the relationship between biodiversity loss and the entire functioning of the ecosystem (Udofia et al., 2014). The high rate at which plant species destruction occurs is aggravated by the conversion of forest lands into agricultural fields, collection of non-timber forest products (NTFPs) and indiscriminate bush fire, road construction, technological advancement, industrialization and urbanization, extraction of matured trees and collection of fuel wood. One or a combination of these actions can threaten or encourage extinction of some aspect or entirety of plant biodiversity, which in turn poses a threat to the sustainable conservation of biodiversity (Mogaka, 2002). Furthermore, the plantation of exotic species, established either as forest stands within the indigenous forest or as individual trees for enrichment planting as part of the management plans to encourage softwood production, protection of indigenous forests and mitigate against soil erosion have inadvertently exacerbated the threats to biodiversity in these forests (Rogo and Oguge, 2000; Pelikka et al., 2009).

Alterations in species composition also emanate when a forest has been degraded which can also affects biodiversity. Decreased forest cover is a type of forest degradation which not only leads to biodiversity loss but also the loss of ecosystem functions such as pest control and pollination, seed dispersal and provision of water resources (Laurence et al., 2002; Forley et al., 2007; Scot and Lesch, 2007).
Continued existence of these forests and their plant species is in jeopardy due to different disturbances that can either be natural or anthropogenic which could range from deforestation, logging, flooding, erosion, fire outbreaks etc., all of which are drastically on the increase in recent times thereby posing an appreciable risk to local extinction of some of these species (Nodza et al., 2014). These coupled with rapid population increase and the need for urbanization have led to the development of several infrastructural facilities so as to provide humans with their insatiable wants, have caused the destruction of more forest vegetation within and outside the study area thereby posing serious socioeconomic problems that are becoming too difficult to control. Hence, an attempt to establish tree species diversity status between undisturbed and disturbed forest fragments of the Kakulu forest becomes necessary to provide baseline information for further research with consequent contribution to the highly demanding environmental challenges.

\section{Material and Methods Study Area}

This study was carried out in Kakulu forest located behind the new yam market in Zing town of Zing local government area of Taraba State (Lat: $8^{\circ} 45^{\prime}$ and $9^{\circ} 10^{\prime} \mathrm{N}$; Long: $11^{\circ} 35^{\prime}$ and $\left.11^{\circ} 50^{\prime} \mathrm{E}\right)$. It has a land mass of $867 \mathrm{Km}^{2}$ and a population of about 127,362 inhabitants having an annual growth rate of 3.0 percent (NPC, 2006). The climate is typical of the tropics with a marked dry and rainy season. The rainy season spread over a period of seven months from April to October with a mean annual rainfall that range from 819$1761 \mathrm{~mm}$ and a dry season that spans from November to March with a mean annual temperature of about $28^{\circ} \mathrm{C}$ (Yusuf and Ray, 2011). 


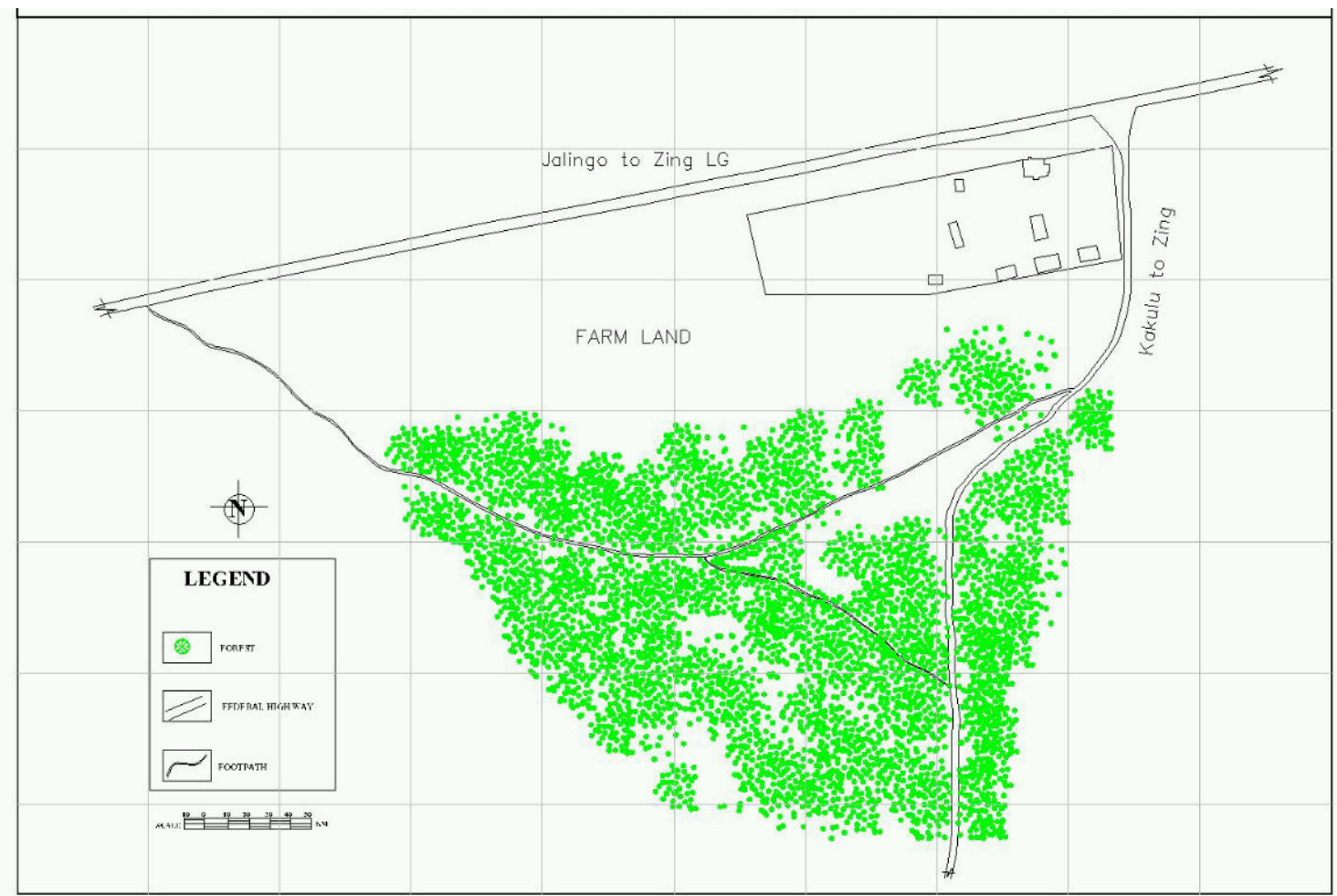

Source: Natural Resources Department, Zing LGA.

Figure 1: Aerial Map of Kakulu Forest, Zing L.G.A. Taraba State

\section{Data Collection}

A transect of size $30 \times 30$ meter square was mapped out in each of the identified fragments for consistent survey and monitoring of tree species composition. These plots were further made into subplots of $5 \mathrm{~m}^{2}$ from where tree species were identified, their circumference and height at first branch recorded and their densities determined. For the purpose of this study, a tree was considered to be any free standing plant that attains a diameter at breast height $(\mathrm{DBH})$ of at least $1 \mathrm{~cm}$.

For identification, plant specimens were collected and made into a plant press for preservation and transportation, according to the procedures outlined by the Herb Society of America (HSA), manual 2005. All other measurements were conducted with the help of a measuring tape of 50m length.

\section{Data Analysis}

Species diversity was calculated using the Shannon-Weiner (H') Diversity Index as proposed by Shannon (1948), which was chosen because of its ability of providing both the estimate in terms of abundance and evenness and does not favor some species over others as all species are counted according to frequencies as follows;

$\mathrm{H}^{\prime}=-\sum \mathrm{pi} \ln \mathrm{pi}-\quad-\quad \quad-\quad \mathrm{i}$

Where $\mathrm{i}$ is the proportion of the plant species relative to the total number of species (pi) multiply by the natural logarithm of this proportion (ln pi) and the final product multiply by -1 .

$\mathrm{S}=\sum \mathrm{n} \quad-\quad \mathrm{n} \quad-\quad-\quad$ ii

Where, $\mathrm{n}$ is the number of species in a community, while species evenness was assessed by the Shannon's Equitability Index (H'E), calculated as; 
$\mathrm{H}^{\prime} \mathrm{E}=\mathrm{H}^{\prime} / \mathrm{H}_{\max }{ }^{-} \quad-\quad-\quad$ iii

Where $\mathrm{H}_{\max }$ is defined as $\ln S$.

Students t-test was further used to compared the statistical difference between values of Shannon-Weiner Index obtained from the two sites within the forest, as described by Jayaraman (1999) and given as;

$$
\mathrm{t}=\frac{\mathrm{H}_{1}-\mathrm{H}_{2} \mathrm{l}}{\sqrt{\operatorname{var}(\mathbf{H} 1)+\operatorname{var}(\mathbf{H} 2)}}
$$

With a degree of freedom given as;

$$
\mathrm{V}=\frac{\left[\operatorname{var}\left(\mathrm{H}_{1}\right)+\operatorname{var}\left(\mathrm{H}_{2}\right)\right]^{2}}{\left[\operatorname{var}\left(\mathrm{H}_{1}\right)\right]^{2} / \mathrm{N}_{1}+\left[\operatorname{var}\left(\mathrm{H}_{2}\right)\right]^{2} / \mathrm{N}_{2}}
$$

\section{Results}

The results in Table 1 indicate that Kakulu forest structure comprises of 38 species of trees belonging to 23 families based on the plot sampling technique. Out of the 38 species occurring in theforest, Isobalinia doka $(\mathrm{n}=411,29.63 \%)$ is the most abundant species, followed by Dicrostachys cinerea $(\mathrm{n}=217,15.65 \%)$ and Isobalinia tomentosa $\quad(\mathrm{n}=123, \quad 8.87 \%)$ while Terminalia ancennoides and Ekerbegia senegalensi had $(\mathrm{n}=1,0.07 \%)$ each and Cussonia barterii, Khaya senegalensis, Parkia biglobosa, and Parinari curatellifolia had $(\mathrm{n}=2,0.14 \%)$ each as the least in abundance.
In Table 2, the tilled fragment showed low species richness of 500 individuals than the untilled fragment which is more natural and undisturbed, having species richness of 887 tree species. Cissus coniflora, Combretum lasiocarpum, Guieria senegalensis, Heeria insignis, Ochna afzellia, Sechium edule, Securinega virosa, Swartzia madagascariensis and Terminalia ancennoides were absent in the tilled fragment while in the untilled fragment Bombax costatum, Isobalinia tomentosa, Khaya senegalensis, Nauclea latifolia, Parkia biglobosa, Parinari curatellifolia, Prosopis africana, and Stereospermum kunthianum were the species observed to be absent. The Shannon-Weigner Diversity Index showed that the two fragments have diversity indices of $\mathrm{H}_{1}=2.3505$ and $\mathrm{H}_{2}=2.3448$ which proves that the fragments are disturbed although the values are statistically not significant ( $p>0.05$ ) based on t-test analysis. Species evenness in the two sites had values of 0.1473 and 0.1611 respectively. In the tilled fragment, Isobalinia tormentosa had the highest Relative Density of 24.6 while Brigdelia ferruginea and Cussonia barterii were the least with RD of 0.2 each. In the untilled fragment Isobalinia doka had the highest Relative Density of 34.6 while Terminalia ancennoides, Ekerbergia senegalensis, Daniella oliveri and Cussonia barterii had the lowest RD of 0.1 each. 
Table 1: Checklist of Tree Species in Kakulu Forest

\begin{tabular}{|c|c|c|c|}
\hline Species & Family & Specie Number & $\%$ Frequency \\
\hline Anonna senegalensis & Anonnaceae & 35 & 2.52 \\
\hline Bombax costatum & Malvaceae & 3 & 0.22 \\
\hline Brigdelia ferniginea & Euphorbiaceae & 38 & 2.74 \\
\hline Cissus coniflora & Vitaceae & 4 & 0.29 \\
\hline Combretum lasiocarpum & Combretaceae & 11 & 0.79 \\
\hline Cussonia barterri & Araliaceae & 2 & 0.14 \\
\hline Daniella oliveri & Fabaceae & 8 & 0.58 \\
\hline Detarium microcarpum & Fabaceae & 32 & 2.31 \\
\hline Dicrostachys cinerea & Fabaceae & 217 & 15.65 \\
\hline Diaspyrosi mesipilitormis & Ebenaceae & 8 & 0.58 \\
\hline Entada Africana & Fabaceae & 12 & 0.87 \\
\hline Ekerbergia senegalensis & Maliaceae & 1 & 0.07 \\
\hline Ficus sycomurus & Moraceae & 6 & 0.43 \\
\hline Gardenia aqualla & Combretaceae & 11 & 0.79 \\
\hline Guieria senegalensis & Combretaceae & 2 & 0.14 \\
\hline Heeria insignis & Anacardiaceae & 6 & 0.43 \\
\hline Hymenocarlia acida & Euphorbiaceae & 9 & 0.65 \\
\hline Isoberlinia doka & Fabaceae & 411 & 29.63 \\
\hline Isoberlinia tementosa & Fabaceae & 123 & 8.87 \\
\hline Khaya senegalensis & Maliaceae & 2 & 0.14 \\
\hline Lannea acida & Anacardiaceae & 12 & 0.87 \\
\hline Nauclea latifolia & Rubiaceae & 4 & 0.29 \\
\hline Ochna afzelii & Ochnaceae & 102 & 7.35 \\
\hline Parkia biglobosa & Mimosoideae & 2 & 0.14 \\
\hline Parinari curatellifolia & Chnysobelanaceae & 2 & 0.14 \\
\hline Poliostigma thonningii & Fabaceae & 32 & 2.31 \\
\hline Prosopis Africana & Mimosoideae & 7 & 0.50 \\
\hline Psorospormum senegalensis & Gultiferae & 19 & 1.37 \\
\hline Sechium edule & Cucurbitaceae & 95 & 6.85 \\
\hline Securidacalongi pedunculata & Polygalaceae & 23 & 1.66 \\
\hline Securinega virosa & Euphorbiaceae & 31 & 2.24 \\
\hline Stereospermum kunthianum & Bignoniaceae & 11 & 0.79 \\
\hline Strychnos spinosa & Liganiaceae & 21 & 1.51 \\
\hline Swartzia madagascariensis & Fabaceae & 10 & 0.72 \\
\hline Terminalia ancennoides & Combretaceae & 1 & 0.07 \\
\hline Terminalia mollis & Combretaceae & 30 & 2.16 \\
\hline Vitellaria paradoxa & Spoztaceae & 31 & 2.24 \\
\hline Vitex doniana & Verbenaceae & 13 & 0.94 \\
\hline Total & & 1387 & 100 \\
\hline
\end{tabular}


BARAU et al.

Table 2: Tree Species Diversity in Kakulu Forest

\begin{tabular}{|c|c|c|c|c|c|c|c|}
\hline \multirow[t]{2}{*}{ Species Found } & \multirow[t]{2}{*}{ Family } & \multicolumn{3}{|c|}{ Fragment One } & \multicolumn{3}{|c|}{ Fragment Two } \\
\hline & & $\mathrm{RD}$ & $\mathrm{Pi}$ & PilnPi & $\mathrm{RD}$ & $\mathrm{Pi}$ & PilnPi \\
\hline Anonna senegalensis & Anonnaceae & 4.8 & 0.0480 & -0.1458 & 1.2 & 0.0124 & -0.0544 \\
\hline Bombax costatum & Malvaceae & 0.6 & 0.0061 & -0.0307 & 0.0 & - & - \\
\hline Brigdelia ferniginea & Euphorbiaceae & 0.2 & 0.0580 & -0.1651 & 1.0 & 0.0101 & -0.0464 \\
\hline Cissus coniflora & Vitaceae & 0.0 & - & - & 0.5 & 0.0045 & -0.0243 \\
\hline Combretum lasiocarpum & Combretaceae & 0.0 & - & - & 1.2 & 0.0124 & -0.0544 \\
\hline Cussonia barteri & Araliaceae & 0.2 & 0.0020 & -0.0124 & 0.1 & 0.0011 & -0.0075 \\
\hline Daniella oliveri & Fabaceae & 1.4 & 0.0140 & -0.0598 & 0.1 & 0.0011 & -0.0075 \\
\hline Detarium microcarpum & Fabaceae & 0.0 & - & - & 3.6 & 0.0361 & -0.1199 \\
\hline Dicrostachys cinerea & Fabaceae & 19.0 & 0.1900 & -0.3155 & 13.8 & 0.1375 & -.02728 \\
\hline Diaspyrosi mesipilitormis & Ebenaceae & 0.0 & - & - & 0.9 & 0.0090 & -0.0424 \\
\hline Entada Africana & Fabaceae & 0.4 & 0.0042 & -0.0221 & 1.1 & 0.0113 & -0.0507 \\
\hline Ekerbergia senegalensis & Maliaceae & 0.0 & - & - & 0.1 & 0.0011 & -0.0075 \\
\hline Ficus sycomurus & Moraceae & 0.6 & 0.0061 & -0.0307 & 0.3 & 0.0034 & -0.0193 \\
\hline Gardenia aqualla & Combretaceae & 1.0 & 0.0100 & -0.0461 & 0.7 & 0.0068 & -0.0339 \\
\hline Guieria senegalensis & Combretaceae & 0.0 & - & - & 0.2 & 0.0023 & -0.0140 \\
\hline Heeria insignis & Anacardiaceae & 0.0 & - & - & 0.7 & 0.0068 & -0.0339 \\
\hline Hymenocarlia acida & Euphorbiaceae & 1.4 & 0.0140 & -0.0598 & 0.2 & 0.0023 & -0.0140 \\
\hline Isoberlinia doka & Fabaceae & 20.8 & 0.2080 & -0.3266 & 34.6 & 0.3461 & -0.3672 \\
\hline Isoberlinia tementosa & Fabaceae & 24.6 & 0.2460 & -0.3450 & 0.0 & - & - \\
\hline Khaya senegalensis & Maliaceae & 0.4 & 0.0042 & -0.0221 & 0.0 & - & - \\
\hline Lannea acida & Anacardiaceae & 0.8 & 0.0080 & -0.0386 & 0.9 & 0.0090 & -0.0424 \\
\hline Nauclea latifolia & Rubiaceae & 0.8 & 0.0080 & -0.0386 & 0.0 & - & - \\
\hline Ochna afzelii & Ochnaceae & 0.0 & - & - & 11.5 & 0.1150 & -0.2487 \\
\hline Parkia biglobosa & Mimosoideae & 0.4 & 0.0042 & -0.0221 & 0.0 & - & - \\
\hline Parinari curatellifolia & Chrysobalanacea & 0.4 & 0.0042 & -0.0221 & 0.0 & - & - \\
\hline Poliostigma thonningii & Fabaceae & 3.0 & 0.0300 & -0.1052 & 1.9 & 0.0192 & -0.0759 \\
\hline Prosopis Africana & Mimosoideae & 1.4 & 0.0140 & -0.0598 & 0.0 & - & - \\
\hline Psorospormum senegalensis & Gultiferae & 2.6 & 0.0260 & -0.0949 & 0.7 & 0.0068 & -0.0339 \\
\hline Sechium edule & Cucurbitaceae & 0.0 & - & - & 10.7 & 0.1071 & -0.2393 \\
\hline Securidacalongi pedunculata & Polygalaceae & 0.6 & 0.0061 & -0.0307 & 2.3 & 0.0225 & -0.0854 \\
\hline Securinega virosa & Euphorbiaceae & 0.0 & - & - & 3.5 & 0.0349 & -0.1171 \\
\hline Stereospermum kunthianum & Bignoniaceae & 2.2 & 0.0220 & -0.0840 & 0.0 & - & - \\
\hline Strychnos spinosa & Liganiaceae & 1.2 & 0.0120 & -0.0531 & 1.7 & 0.0169 & -0.0690 \\
\hline Swartzia madagascariensis & Fabaceae & 0.0 & - & - & 1.1 & 0.0113 & -0.0507 \\
\hline Terminalia ancennoides & Combretaceae & 0.0 & - & - & 0.1 & 0.0011 & -0.0075 \\
\hline Terminalia mollis & Combretaceae & 1.6 & 0.0160 & -0.0662 & 2.5 & 0.0248 & -0.0917 \\
\hline Vitellaria paradoxa & Spoztaceae & 2.6 & 0.0260 & -0.0949 & 2.0 & 0.0203 & -0.0791 \\
\hline Vitellaria doniana & Verbenaceae & 1.4 & 0.0140 & -0.0598 & 0.7 & 0.0068 & -0.0340 \\
\hline
\end{tabular}

$\mathrm{H}_{1}{ }_{1}=2.3505, \operatorname{var}\left(\mathrm{H}_{1}\right)=0.0578, \quad \mathrm{H}^{\prime} \mathrm{E}_{1}=0.1473, \quad \mathrm{~N}_{1}=500, \quad \mathrm{H}_{2}{ }_{2}=2.3448, \operatorname{var}\left(\mathrm{H}_{2}\right)=0.0621, \quad \mathrm{H}^{\prime} \mathrm{E}_{2}=0.1611$ $\mathrm{N}_{2}=887, \mathrm{v}(\mathrm{df})=1307, \mathrm{t}_{\mathrm{cal}}=0.0032, \mathrm{t}_{\mathrm{tab}(0.05)}=2.6$ 


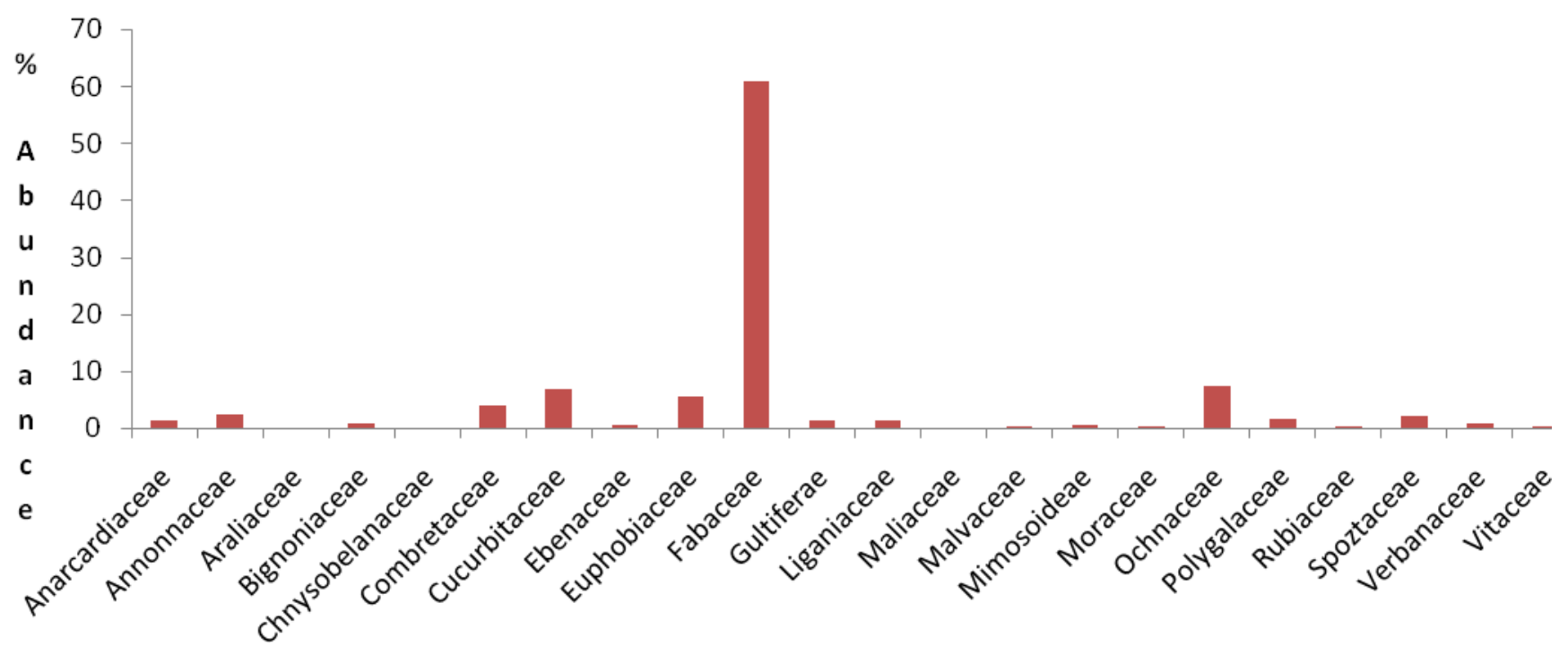

Trees Families

Figure 1: Species Abundance Based on Families

From the figure above the family Fabaceae had the highest abundance of $(60.92 \%)$, followed by Ochnaceae $(7.35 \%)$ then Cucurbitaceae $(6.85 \%)$ and the least in abundance were Maliacea $(0.07 \%)$, Araliaceae and Chnysobelanaceae $(0.14 \%$ each) and Malvaceae $(0.21 \%)$.

\section{Discussion}

It may not be out of place to say that this geographical zone was formally a natural forested land that perhaps has suffered destruction due to anthropogenic activities. Therefore, based on natural history, this forest patch in question could be classified as living on the edge and thereby requiring concerted effort from both governmental and non-governmental organizations to revive its natural stature. Forests are very important as watershed catchment areas, habitats for wildlife ranging from soil microorganisms to terrestrial populations, environmental balance and renewal of ecosystemic processes, and above all clothes the soil to prevent erosion.

The high tree species richness (38 taxa) observed in this study may be an underestimation of the whole area at its natural state. This is because the study area was observed to be surrounded by open and bare farmlands suggesting that the original natural forest that existed before was removed to allow for short term agriculturally productive lands. On the contrary, some tree species occurring in the study area may not have existed in a wider range, probably because its origin might be in the study area and the unfavorable human activities in the surroundings have restricted its expansion. Similarly, over disturbances in neighbouring land might have favored the fate of seed dispersal in the study area, hence, the high species richness. This report agrees with Dangu (2015) who found out that the fate of seeds after predation were higher in protected than unprotected forest fragments.

There were a total of 1387 tree stands observed in the study area with great difference in the number of occurrence. Furthermore, chi- square $\left(\chi^{2}\right)$ statistical test revealed a significant difference $(\mathrm{p}>0.05)$ in the number of tree species in the study area with some trees as high as 411 
individuals (I. doka) while others scored as low as a single stand (E. senegalensis). These marked difference many not be unconnected to human preference in relation to utilization as those species with low number may be most preferred for either firewood, local house construction, timber, yam farming or their fruits, leaves and flowers are important forest minor products to the people of the area. Such pressure from humans on economic trees would perhaps reduce reproductive potentials. This situation could probably pave way for non-reproductive cycle or simply the seedlings may be destroyed due to its flexibility and palatability. Some tree species may be successful through reproductive stages and optimum performance yet seed dispersal mechanisms could restrict its regeneration; a situation whereby those with smaller seed sizes are easily dispersed than those with bigger seeds because the bigger seeds will require larger mammals or birds. However, these categories of animals are endangered or even extinct from most areas of origin. Some seed dormancy are only broken after being fed upon by animals and released as faeces. Therefore, the presence or absence of such seed dispersal agents will likely have consequential positive or adverse effect on its germination and regeneration, hence, abundance is also affected.

This result conforms to the work of many researchers among which are Edet $e t$ al. (2012), who reported that there were more plant species in Afi Mountain Wildlife Sanctuary than in the communal forest. Udofia et al. (2014) also reported that more tree composition was observed in Ayan Nsit sacred forest than in the adjourning community forest. Omoro et al. (2010), also reported a significant difference in diversity values between indigenous forest and exotic ones in the cloud forests of eastern arc mountains, taita hills, Kenya because in the exotic forest, species are cuts for different purposes. This is probably because of the anthropogenic impacts occasioned by bush burning and agricultural practices that tend to accumulate more pressure on the resources of the forest. Over exploitation and utter conversion of the forest ecosystem results in the decimation of plant species (Iroko et al., 2008). The above result also shows the likelihood of the species in the tilled fragment becoming threatened in the future resulting to the disappearance of many important plant species leading to the disappearance of the forest and the subsequent loss of the forests various important uses and roles.

\section{Conclusion and Recommendation}

Based on the findings of this study, it may not be out of place to conclude that Kakulu forest of Zing local government area in Taraba State is still at its natural state with minimal human disturbance. It is made up of an interspersion of savannah trees, the forest had high numbers in both species richness and individuals, and the low number seen in some cases may be an indication of human destructive nature. Therefore, it is recommended that concerted effort from both governmental and non-governmental organizations is highly needed to prevent further demise and improve on its current status for posterity.

\section{Acknowledgement}

The authors wish to acknowledge the Department of Agriculture and Natural Resources and the entire Management of Zing Local Government Council for granting us the permission to embark on this study. And also to those so many who helped in one or the other at different stages of this research and whose names 
could not be mentioned, we are very grateful, and lastly to those eyes that read through the manuscripts, your cricitisms gave this work the much deserved quality, thank you all.

\section{Reference}

Adeyemi, T.O. and Ogundipe, O.T. (2012). Biodiversity of Sapindaceae in West Africa: A Checklist: International Journal of Biodiversity and Conservation, 4(10): 358-363.

Davis, G. and Richardson, D. (1995). The functions of biodiversity. Mediterranean Type ecosystems. Springer, Berlin. Pp 11-19.

Edet, I.D., Henry, M.I. and Augustine, U.O. (2012): Preliminary assessment of tree species diversity in Afi Mountain Wildlife Sanctuary, Southern Nigeria. Agriculture and Biology Journal of North America @www.schb.org/ABJNA.

Forley, J.A., Asner, G.P., Costa, M.H., Coe, M.T., Defries, R., Gibbs, H.K., Howard, E.A., Olson, S., Patz, J., Ramankutty, N. and Snyder, P. (2007): Amazonian revealed: forest degradation and loss of ecosystem goods and services in the Amazon basin. Ecological Society of America, 5: 25-32.

Dangu, G.G. (2015). The fate of Carap grandiflora seed in Ngel-Nyaki Forest Reserve, Nigeria. Unpublished B.sc thesis, Department of Biological Sciences, Taraba State University, Jalingo, 51pp.

Herb Society of America (2005). The Use and Methods of Making a Herbarium/Plant Specimen. 9019 Kirtland Chadron $\mathrm{Rd}$, Kirtland, $\mathrm{OH}$ 44094

Iroko, O.A., Kareem, A.A., Aido, A.F. and Gbadebo, J.O. (2008). Impact of Human Activities on the forest and their effect on climate change. Journal of Applied Science, 4(2): 122-131.

Jayaraman, K. (1999). A statistical manual for forestry research. Food and Agriculture Organization of the United Nations (FAO) Regional Office for Asia and the Pacific, Bankok. Pp. 191-196.

Laurence, W.F., Nascimento, H.E.M., Laurance, S.G., Andorales, A. Rebeiro, J., Giraldo, J.P., Le Maitre, D.C., Van Wilgen, B.W Gelderbloom, C.M., Bailey, C., Chapman, R.A, and Nel, J.A. (2002). Invasive alien trees and water resources in South Africa: Case studies of the costs and benefits of management. Forest Ecology and Management, 160:143-159.

Mogaka, H. (2002). Economic instrument for the reduction of biodiversity loss in Kenya. GEF/UNDP/FAO Cross Border Biodiversity ProjectReducing Biodiversity at selected Cross Border sites in East Africa. Economic component technical report, no. 16. 43Pp.

National Population Commission (2006). Population Census figures for states and local governments @www.npc.crnsusfigures.org.ng

Nodza, I.G., Onuminya, T.O. and Ogundipe, O.T. (2014). A Checklist of trees species growing in Akoka campus of University of Lagos, Nigeria. International Journal of Science, Environment and Technology. 3(3): 1021-1034.

Omoro, L.M.A., Pelikka, P.K.E. and Rogers, P. C. (2010). Tree species diversity richness and similarity between exotic and indigenous forest in the cloud forests of eastern arc mountains, Taita Hills, Kenya. 
Journal of Forestry Research, 21(3): 255-264.

Pelikka, P., Lotjonen, M., Siljander, M. and Lens, L. (2009). Airborne remote sensing of spatiotemporal changes (1955-2004) in indigenous and exotic forest cover in the Taita Hills, Kenya. International Journal of Applied Earth Observations and Geoinformation. 11(4): 221-232.

Rogo, L. and Oguge, N. (2000). The Taita Hills forest remnant: a disappearing world heritage. Ambio., 29: 522-523.

Scot, D. F. and Lesch, W. (2007). Streamflow responses to afforestation with Eucalyptus grandis and Pinus patula and to felling in the mokobulaan experimental catchments, South Africa. Journal of Hydrobiology, 199: 360-377.

Solbrig, O.T. (1991). From genes to ecosystem: A research agenda for biodiversity. IMBS-SCOPE, UNESCO, Harvard, Cambridge.

Udofia, S.I., Owoh, P.W., Attah, V.I. and Thomas, A.D. (2014). Assessment of plant species composition in Ayan Nsit sacred forest of Akwa Ibom State, Nigeria. Nigerian

Journal of Agriculture, Food and Environment 10(2): 34-37.

Yusuf, M.B. and Ray, H.H. (2011). Farmers perception and responses to soil erosion in Zing local government area of taraba state. Ethiopian Journal of Environmental Studies and Management 4(1): 231-237. 